\title{
The effect of acute exposure to herbicide Gardoprim Plus Gold 500 SC on haematological and biochemical indicators and histopathological changes in common carp (Cyprinus carpio L.)
}

\author{
Radka Dobšíková1, Jana Blahová1, Helena Modrá1, Miša Škorič², Zdeňka Svobodová1 \\ ${ }^{1}$ Department of Veterinary Public Health and Toxicology, Faculty of Veterinary Hygiene and Ecology, \\ University of Veterinary and Pharmaceutical Sciences Brno, Czech Republic \\ ${ }^{2}$ Department of Pathological Morphology and Parasitology, Faculty of Veterinary Medicine, \\ University of Veterinary and Pharmaceutical Sciences Brno, Czech Republic
}

Received September 8, 2011

Accepted November 15, 2011

\begin{abstract}
The study was focused on the assessment of effects of herbicide preparation Gardoprim Plus Gold 500 SC (terbuthylazine and S-metolachlor as active substances) on haematological and biochemical indices as well as tissue histopathological changes in common carp (Cyprinus carpio L.). Forty eight one- to two-year-old fish were divided into two groups, i.e. 24 fish were treated with $13.0 \mathrm{mg} \cdot \mathrm{l}^{-1}$ of Gardoprim Plus Gold $500 \mathrm{SC}$ and 24 fish were used in control. The experiment was conducted according to OECD method No. 203 Fish, Acute Toxicity Test. Experimental carp showed a significant decrease in leukocyte and lymphocyte counts $(P<0.01)$ and haematocrit value $(P<0.05)$ in haematological profile. In biochemical indices, a significant increase in glucose, aspartate aminotransferase, ammonia $(P<0.01)$, and lactate dehydrogenase $(P<0.05)$ and a significant decrease in inorganic phosphorus, triglycerides $(P<0.01)$, and chlorides $(P<0.05)$ were found in exposed carp compared to control. Histopathological examination revealed lesions in gills and liver. The decline in both leukocyte and lymphocyte counts indicates decreased nonspecific immunity of treated common carp. Increase in ammonia and glucose concentrations, and in catalytic activities of lactate dehydrogenase and aspartate aminotransferase can be related to stress burden, and alteration of liver cell function, respectively, in experimental carp compared to control fish. The study uniquely contributes to the evaluation of the effect of two-component herbicide preparation on common carp.
\end{abstract}

Terbuthylazine, S-metolachlor, fish, acute toxicity

Triazine herbicides belong to the most well known and widely used pesticide group. Triazine substance terbuthylazine has been replacing the better known and longer used and studied atrazine in several regions of the world. It is used as a broad spectrum preor post-emergence. It is stable in neutral, weakly acid and weakly alkaline media. Water solubility of terbuthylazine is $8.5 \mathrm{mg} \cdot \mathrm{l}^{-1}$ at $20{ }^{\circ} \mathrm{C}$ (Gangolli $1999 \mathrm{~b}$ ). There are studies on terbuthylazine toxicity to terrestrial animals (Lang et al. 1997), but less is known about its toxicity to aquatic organisms, including fish (Dezfuli et al. 2006).

Chloracetanilide herbicides are used to control annual grasses and broad leaf weeds. Chloracetanilide metolachlor has been used to control annual grass and broad-leaved weeds following pre-emergence application for more than 20 years. Metolachlor is relatively soluble in water with $488 \mathrm{mg} \cdot \cdot^{-1}$ at $25^{\circ} \mathrm{C}$ (Gangolli 1999a). There are several studies on the toxicity of metolachlor to terrestrial and aquatic organisms (Wan et al. 2006).

The aim of this study is to assess the effect of the herbicide Gardoprim Plus Gold 500 SC (187.5 g. $\mathrm{l}^{-1}$ of triazine terbuthylazine and $312.5 \mathrm{~g} \cdot \mathrm{l}^{-1}$ of chloracetanilide S-metolachlor) on both haematological and biochemical indicators, and tissue histopathological changes of exposed common carp. The hypothesis of synergistic effect of triazine- and acetanilidebased active substances contained in composite commercial preparation on fish immune system status, stress burden and tissue impairment was evaluated. 


\section{Materials and Methods}

One- to two-year-old common carp (Cyprinus carpio L.) of $93.66 \pm 31.77 \mathrm{~g}$ and $18.28 \pm 2.15 \mathrm{~cm}$ body weight and body length, respectively, were used for the assessment. Twenty four carp (experimental group) were exposed to $13.0 \mathrm{mg} \cdot \mathrm{l}^{-1}$ of Gardoprim Plus Gold $500 \mathrm{SC}$ (corresponding to $2.25 \mathrm{mg} \cdot \cdot^{-1}$ and $3.75 \mathrm{mg} \cdot \mathrm{l}^{-1} \mathrm{of}$ terbuthylazine and S-metolachlor, respectively). Other twenty four carp (control group) were kept in water. Experimental and control groups of carp were divided into 2 duplicates, i.e. twelve fish individuals were kept in each 2001 aquarium (two aquaria with $13.0 \mathrm{mg} \cdot \mathrm{l}^{-1}$ of the herbicide, two control aquaria).

A 96-hour toxicity test was performed semistatically with water renewal every $24 \mathrm{~h}$. According to the OECD No. 203 Fish, Acute Toxicity Test, the concentration of active substances in test water was maintained above $80 \%$. Terbuthylazine and S-metolachlor concentrations were determined using GC/MS/MS method.

Blood samples were taken by cardiocentesis. Heparinized blood samples were used for the evaluation of haematological indicators including haematocrit (PCV), erythrocyte count (RBC), haemoglobin concentration $(\mathrm{Hb})$, mean erythrocyte volume $(\mathrm{MCV})$, mean erythrocyte haemoglobin $(\mathrm{MCH})$, mean corpuscular haemoglobin concentration (MCHC), leukocyte count (WBC), and differential leukocyte count (Svobodova et al. 1991).

A part of heparinized blood was centrifuged at $855 \mathrm{~g}$ for $10 \mathrm{~min}$ and used for biochemical analysis. Biochemical indicators including glucose (GLU), lactate (LACT), total proteins (TP), albumins (ALB), ammonia $\left(\mathrm{NH}_{3}\right)$, triacylglycerols (TRIG), aspartate aminotransferase (AST), alanine aminotransferase (ALT), alkaline phosphatase (ALP), lactate dehydrogenase (LDH), calcium $\left(\mathrm{Ca}^{2+}\right)$, inorganic phosphate (PHOS) were measured by a COBAS MIRA automatic analyser (Hoffman, La Roche, Co., Switzerland) using BioVendor Tests. Natrium $\left(\mathrm{Na}^{+}\right)$and chloride $\left(\mathrm{Cl}^{-}\right)$concentrations were analysed using Easy Lyte Analyzer (Medica Corp., Bedford, MA, USA).

Tissue samples of gills, liver, and kidneys were fixed in buffered $10 \%$ neutral formalin, dehydrated, embedded in paraffin wax, sectioned on a microtome at a thickness of $4 \mu \mathrm{m}$, and stained with haematoxylin and eosin (HE). The sections were examined by light microscopy and photographed by a digital camera.

Statistical analysis of the data was conducted using Statistica 8.0 for Windows (StatSoft, Inc., USA). Values were tested for normal distribution using Kolmogorov-Smirnov test and log-transformed to improve the homogeneity of variance. A one-way analysis of variance (ANOVA) and Tukey-HSD $t$-test were applied.

\section{Results}

During the course of fish exposure to $13.0 \mathrm{mg} \cdot \mathrm{l}^{-1}$ of the herbicide preparation Gardoprim Plus Gold $500 \mathrm{SC}$ (corresponding to $2.25 \mathrm{mg} \cdot \mathrm{l}^{-1}$ and $3.75 \mathrm{mg} \cdot \mathrm{l}^{-1}$ of terbuthylazine and S-metolachlor, respectively) neither mortality nor obvious clinical signs of behavioral, respiratory, and/or neurologic distress were observed in exposed carp.

Table 1. Haematological indicators of control carp and experimental carp treated with $13.0 \mathrm{mg} \cdot \mathrm{l}^{-1}$ of Gardoprim Plus Gold 500 SC

\begin{tabular}{lcc}
\hline Indicators & Control & $\begin{array}{c}\text { Experimental } \\
\text { mean } \pm \text { SD }(\mathrm{n}=24)\end{array}$ \\
\hline $\mathrm{RBC}\left(\mathrm{T} \cdot \mathrm{l}^{-1}\right)$ & $1.24 \pm 0.44$ & $1.10 \pm 0.36$ \\
$\mathrm{Hb}\left(\mathrm{g} \cdot \mathrm{l}^{-1}\right)$ & $86.20 \pm 14.20$ & $86.76 \pm 14.79$ \\
$\mathrm{PCV}\left(\mathrm{l} \cdot \mathrm{l}^{-1}\right)$ & $0.30 \pm 0.04$ & $0.26 \pm 0.04^{*}$ \\
$\mathrm{MCV}(\mathrm{fl})$ & $287.67 \pm 162.55$ & $264.61 \pm 92.41$ \\
$\mathrm{MCH}(\mathrm{pg})$ & $84.54 \pm 42.99$ & $89.78 \pm 24.54$ \\
$\mathrm{MCHC}\left(\mathrm{g} \cdot \mathrm{l}^{-1}\right)$ & $0.30 \pm 0.06$ & $0.33 \pm 0.06$ \\
WBC $\left(\mathrm{G} \cdot \mathrm{l}^{-1}\right)$ & $100.90 \pm 38.38$ & $31.58 \pm 11.28$ \\
Lymphocytes $\left(\mathrm{G} \cdot \mathrm{l}^{-1}\right)$ & $93.76 \pm 34.53$ & $22.94 \pm 10.60$ \\
Monocytes $\left(\mathrm{G} \cdot \mathrm{l}^{-1}\right)$ & $4.27 \pm 2.70$ & $1.34 \pm 0.89$ \\
Neutrophil myelocytes $\left(\mathrm{G} \cdot \mathrm{l}^{-1}\right)$ & $2.74 \pm 1.68$ & $5.40 \pm 3.41$ \\
Neutrophil metamyelocytes $\left(\mathrm{G} \cdot \mathrm{l}^{-1}\right)$ & $2.37 \pm 1.31$ & $5.02 \pm 3.96$ \\
Segmented neutrophiles $\left(\mathrm{G} \cdot \mathrm{l}^{-1}\right)$ & $0.15 \pm 0.29$ & $0.31 \pm 0.73$ \\
\hline
\end{tabular}

Significant difference between test groups $\left({ }^{*} P<0.05 ;{ }^{* *} P<0.01\right)$

RBC - red blood cells, erythrocyte count, Hb - haemoglobin concentration, PCV - haematocrit, MCV mean erythrocyte volume, $\mathrm{MCH}$ - mean erythrocyte haemoglobin, MCHC - mean corpuscular haemoglobin concentration, WBC - leukocyte count 
Table 2. Biochemical indicators of control carp and experimental carp treated with $13.0 \mathrm{mg} \cdot \mathrm{l}^{-1}$ of Gardoprim Plus Gold $500 \mathrm{SC}$

\begin{tabular}{lcc}
\hline Indicators & $\begin{array}{c}\text { Control } \\
\text { mean } \pm \mathrm{SD}(\mathrm{n}=24)\end{array}$ & $\begin{array}{c}\text { Experimental } \\
\text { mean } \pm \mathrm{SD}(\mathrm{n}=24)\end{array}$ \\
\hline $\mathrm{GLU}\left(\mathrm{mmol} \cdot \mathrm{l}^{-1}\right)$ & $5.54 \pm 1.62$ & $9.35 \pm 3.44^{* *}$ \\
$\mathrm{LACT}\left(\mathrm{mmol} \cdot \mathrm{l}^{-1}\right)$ & $1.56 \pm 0.83$ & $1.52 \pm 0.57$ \\
$\mathrm{TP}\left(\mathrm{g} \cdot \mathrm{l}^{-1}\right)$ & $27.57 \pm 3.51$ & $25.08 \pm 4.00$ \\
$\mathrm{ALB}\left(\mathrm{g} \cdot \mathrm{l}^{-1}\right)$ & $15.33 \pm 2.30$ & $13.84 \pm 4.12$ \\
$\mathrm{NH}_{3}\left(\mu \mathrm{mol} \cdot \mathrm{l}^{-1}\right)$ & $243.47 \pm 67.54$ & $322.50 \pm 48.93^{* *}$ \\
$\mathrm{TRIG}\left(\mathrm{mmol} \cdot \mathrm{l}^{-1}\right)$ & $1.60 \pm 0.54$ & $1.12 \pm 0.39^{* *}$ \\
$\mathrm{AST}\left(\mu \mathrm{kat} \cdot \mathrm{l}^{-1}\right)$ & $2.12 \pm 0.98$ & $3.61 \pm 1.65^{* *}$ \\
$\mathrm{ALT}\left(\mu \mathrm{kat} \cdot \mathrm{l}^{-1}\right)$ & $0.20 \pm 0.09$ & $0.29 \pm 0.12$ \\
$\mathrm{ALP}\left(\mu \mathrm{kat} \cdot \mathrm{l}^{-1}\right)$ & $1.24 \pm 0.70$ & $1.06 \pm 0.49$ \\
$\mathrm{LDH}\left(\mu \mathrm{kat} \cdot \mathrm{l}^{-1}\right)$ & $5.78 \pm 3.98$ & $8.26 \pm 4.47^{*}$ \\
$\mathrm{Ca}{ }^{2+}\left(\mathrm{mmol} \cdot \cdot^{-1}\right)$ & $2.58 \pm 0.27$ & $2.42 \pm 0.21$ \\
$\mathrm{PHOS}\left(\mathrm{mmol} \cdot \mathrm{l}^{-1}\right)$ & $1.73 \pm 0.33$ & $1.42 \pm 0.42^{* *}$ \\
$\mathrm{Na}^{+}\left(\mathrm{mmol} \cdot \mathrm{l}^{-1}\right)$ & $125.90 \pm 9.34$ & $121.37 \pm 9.15$ \\
$\mathrm{Cl}^{-}\left(\mathrm{mmol} \cdot \mathrm{l}^{-1}\right)$ & $96.27 \pm 9.17$ & $92.57 \pm 6.55^{*}$ \\
\hline
\end{tabular}

Significant difference between test groups $\left({ }^{*} P<0.05 ;{ }^{* *} P<0.01\right)$

GLU - glucose, LACT - lactate, TP - total proteins, ALB - albumins, $\mathrm{NH}_{3}$ - ammonia, TRIG - triacylglycerols, AST - aspartate aminotransferase, ALT - alanine aminotransferase, ALP - alkaline phosphatase, LDH - lactate dehydrogenase, $\mathrm{Ca}^{2+}$ - calcium, $\mathrm{PHOS}$ - inorganic phosphate, $\mathrm{Na}^{+}$- natrium, $\mathrm{Cl}^{-}$- chloride

The results of haematological examination of control and experimental carp are given in Table 1. The exposure caused a significant decrease in PCV $(P<0.05)$ as well as in leukocyte count (WBC) and lymphocyte count $(P<0.01)$ in experimental carp. The rest of the indices showed no significant differences between experimental and control groups of fish.

The results of plasma biochemical indicators analysis are given in Table 2. A significant increase in glucose, ammonia, AST $(P<0.01)$, and LDH $(P<0.05)$ levels and a significant decrease in triglycerides, inorganic phosphorus $(P<0.01)$, and chlorides $(P<0.05)$ were found in common carp exposed to $13.0 \mathrm{mg} \cdot \mathrm{l}^{-1}$ of the herbicide. The other indicators monitored were found comparable in both fish groups.

Histopathological examination of treated carp revealed pathological lesions in gills and liver (Plate III, Figs 1, 2).

\section{Discussion}

The decrease in PCV in experimental group of common carp could be interpreted as a compensatory mechanism reducing oxygen carrying capacity to maintain gas transfer (Jee et al. 2005). The changes in PCV could be caused by the release of catecholamines during the primary stages of stress, which can mobilize red blood cells swelling as a result of fluid shift into the intracellular compartment (Lebelo et al. 2001). In our study, PCV decrease presumably has a connection with a substantial decline in the RBC count.

The decline in both WBC and lymphocyte counts indicates decreased nonspecific immunity. A change in leukocyte count (WBC) is a sensitive indicator of stress in fish (Feldman et al. 2000). The decrease in lymphocyte count that is usually accompanied by neutrophilia can be associated with stress (Doubek et al. 2010). Analogous changes in WBC and lymphocyte counts were found in common carp exposed to $250.2 \mathrm{mg} \cdot \mathrm{l}^{-1}$ of metribuzin in the preparation Sencor 70 WG (Velisek et al. 2009). Decreased values of $\mathrm{RBC}$ and $\mathrm{Hb}$, but no changes in WBC count and leukocyte profile were found in common 
carp exposed to $2.40 \mathrm{mg} \cdot \mathrm{l}^{-1}$ of alachlor in a chloroacetanilide herbicide Lasso MTX (Mikula et al. 2008).

The increase of glucose can be interpreted as a consequence of glycogenolytic activity of catecholamines and gluconeogenetic effect of glucocorticoids as an organism reaction to the stress stimuli. The concentration of $\mathrm{NH}_{3}$ reflects the grade of urea-synthetic cycle in liver, whereas the cycle insufficiency leads to the elevation of ammonia concentration in blood plasma. Hyperammoniaemia is caused by pathological processes in liver as detoxifying mechanisms are supposedly unable to convert the toxic ammonia to less harmful substances (Doubek et al. 2010). An increase in plasma $\mathrm{NH}_{3}$ concentration was also indicated in common carp exposed to other triazine metribuzin (Velisek et al. 2009).

Both the decreased concentration of TRIG and the increased activity of LDH can be explained as a consequence of pathological changes in hepatic tissue (Doubek et al. 2010). Catalytic activities of plasma enzymes (i.e. LDH, CK, ALT, and AST) may be used as a relevant indicator of stress reaction as the increased values indicate stress-based tissue impairment. Philip et al. (1995) reported that the stress conditions in general amplify the elevation of transamination pathway, i.e. the increase of the transaminases activities. In our study, a significant increase in AST $(P<0.01)$ and LDH $(P<0.05)$ activities was found in exposed carp (Table 2).

Gill lesions were represented by hypertrophy and hyperplasia of epithelial cells with lamellar fusion, hyperaemia (Plate III, Fig. 1, upper arrow) and the presence of multiple foci of coagulation necrosis (Plate III, Fig. 1, lower arrow). Gills usually appear to be one of the most damaged organs due to their direct contact with the toxic substance as they provide a very large interface between the external and internal environment of fish (Oliveira Ribeiro et al. 2002). Fusion of the secondary lamellae and the hyperplasia of gill epithelial cells were also described after the exposure to terbuthylazine (Dezfuli et al. 2006).

Moderate dystrophic lesions, i.e. morphological signs of an initial cell injury represented by swelling and hydropic vacuolar degeneration of hepatocyte, were evident in the liver (Plate III, Fig. 2, arrows). Similar histopathological changes in liver parenchyma (i.e. focal steatosis, hyperaemia, necrosis, fatty dystrophy, glycogen inclusions, vacuolisation) were found in the studies of Dezfuli et al. (2006) and Mikula et al. (2008).

The shifts in both haematological and biochemical indicators, and pathological alteration of tissues reflect the preparation effect on fish immune system (and stress reaction), and the alteration of metabolic pathways especially in fish gills and liver.

\section{Acknowledgements}

The work was realized with the support of MSM Project No. 6215712402 Veterinary Aspects of Foodstuff Safety and Quality.

\section{References}

Dezfuli BS, Simoni E, Giari L, Manera M 2006: Effects of experimental terbuthylazine exposure on the cells of Dicentrarchus labrax (L.). Chemosphere 64: 1684-1694

Doubek J, Slosarkova S, Rehakova K, Bouda J, Scheer P, Piperisova I, Tomenendalova J, Matalova E 2010: The interpretation of basic biochemical and haematological indices in animals. Noviko, Czech Republic (in Czech), $102 \mathrm{p}$.

Feldman BF, Zinkl JG, Jain NC 2000: Schlam's veterinary hematology. Lippincott Williams \& Wilkins, Philadelphia, $1206 \mathrm{p}$.

Gangolli S (Ed.) 1999a: The dictionary of substances and their effect. Vol. 5. The Royal Society of Chemistry, Cambridge, $953 \mathrm{p}$.

Gangolli S (Ed.) 1999b: The dictionary of substances and their effect. Vol. 7. The Royal Society of Chemistry, Cambridge, 998 p.

Jee JH, Masroor F, Kang JC 2005: Responses for cypermethrin-induced stress in haematological parameters of Korean rockfish, Sebastes schlegeli (Hilgendorf). Aquac Res 36: 898-905 
Lang DH, Rettir AE, Bocker RH 1997: Identification of enzymes involved in the metabolism of atrazine, berbuthylazine, ametryne, and terbutryne in human liver microsomes. Chem Res Toxicol 10: 1037-1044

Lebelo SL, Saunders DK, Crawford TB 2001: Observations on blood viscosity in striped bass, Morone saxatilis (Walbaum) associated with fish hatchery contiditons. Trans Kans Acad Sci 104: 183-194

Mikula P, Modra H, Nemethova D, Groch L, Svobodova Z 2008: Effects of subchronic exposure to LASSO $\operatorname{MTX}^{\circledR}$ (Alachlor $42 \% \mathrm{~W} / \mathrm{V}$ ) on hematological indices and histology of the common carp, Cyprinus carpio L. B Environ Contam Tox 81: 475-479

Oliveira Ribeiro CA, Belger L, Pelletier E, Rouleau C 2002: Histopathological evidence of inorganic mercury and methyl mercury toxicity in the arctic charr (Salvelinus alpinus). Environ Res 90: 217-225

Philip GH, Reddy PM, Sridevi G 1995: Cypermethrin-induced in vivo alterations in the carbohydrate metabolism of freshwater fish, Labeo rohita. Ecotox Environ Safe 31: 173-178

Velisek J, Svobodova Z, Piackova V, Sudova E 2009: Effects of acute exposure to metribuzin on some hematological, biochemical and histopathological parameters of common carp (Cyprinus carpio L.). B Environ Contam Tox 82: 482-495

Wan MT, Buday C, Schroeder G, Kuo J, Pasternak J 2006: Toxicity to Daphnia magna, Hyalella azteca, Oncorhynchus kisutch, Oncorhynchus mykiss, Oncorhynchus tshawytscha, and Rana catesbeiana of atrazine, metolachlor, simazine, and their formulated products. B Environ Contam Tox 76: 52-58

Svobodova Z, Pravda D, Palackova J 1991: Unified methods of haematological examination of fish. RIFCH Vodnany, Methods No. 20 (in Czech), 36 p. 
Plate III

Dobšíková R. et al.: The effect of acute ... pp. 359-363

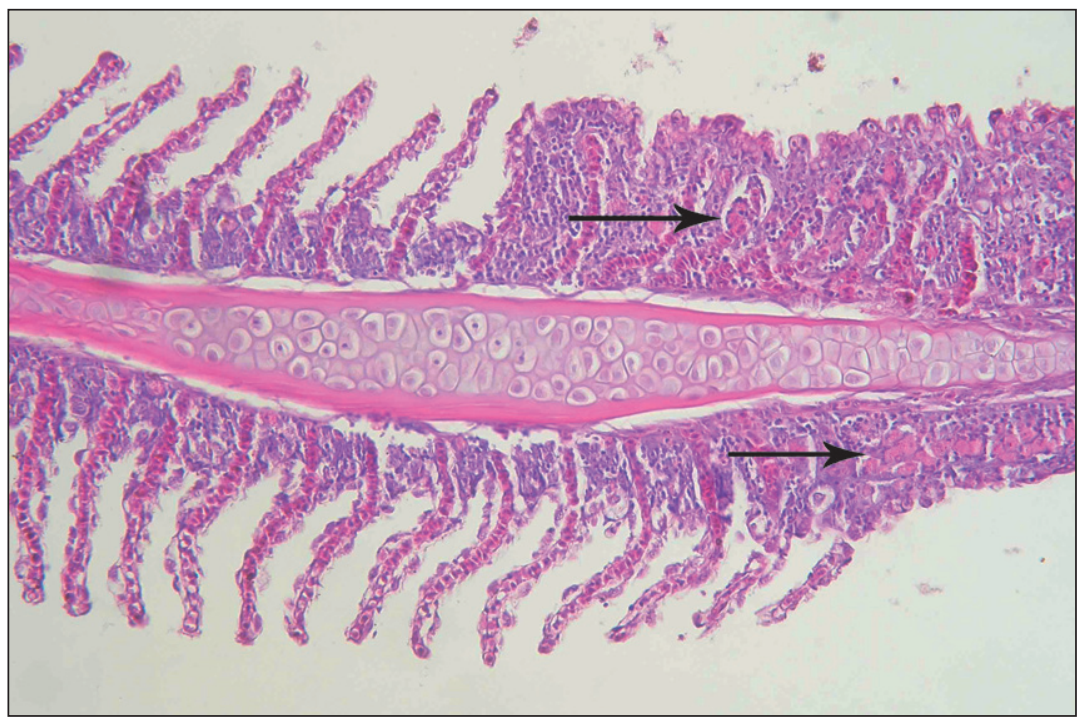

Fig. 1. Gill section of carp treated with $13.0 \mathrm{mg} \cdot \mathrm{l}^{-1}$ of Gardoprim Plus Gold $500 \mathrm{SC}$. Hypertrophy and hyperplasia of epithelial cells with lamellar fusion (upper arrow), multiple foci of coagulation necrosis (lower arrow) $(\mathrm{HE}, \times 200)$.

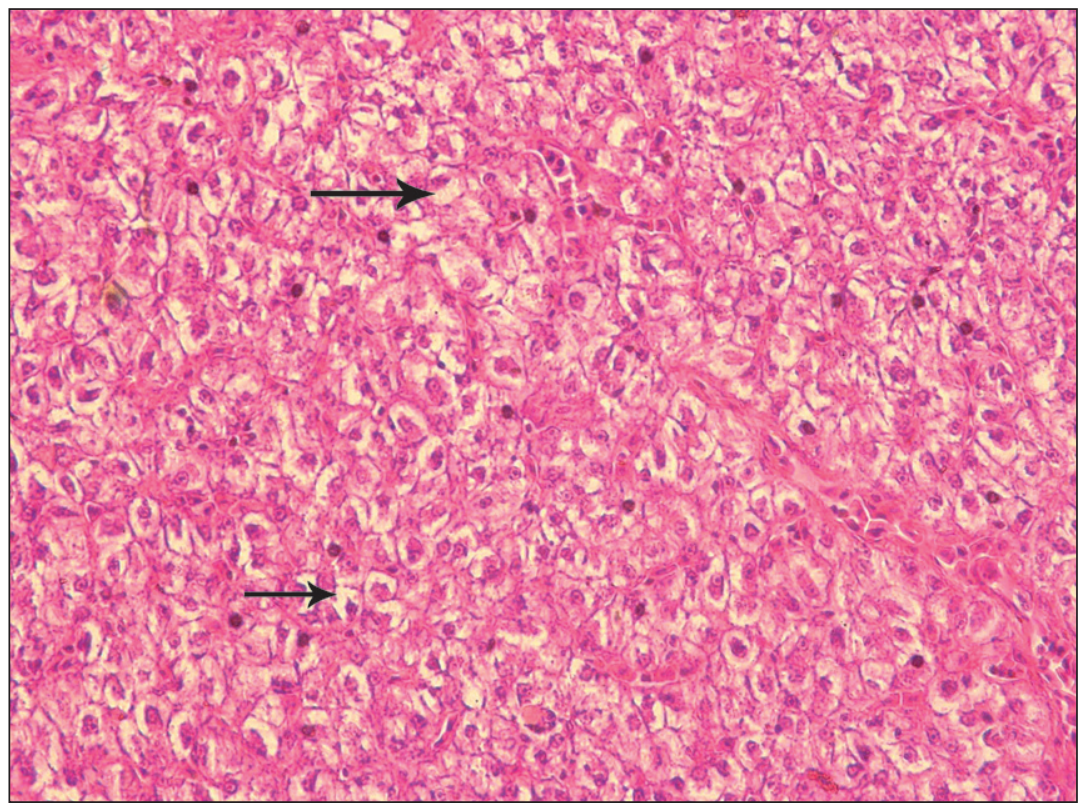

Fig. 2. Liver section of carp treated with $13.0 \mathrm{mg} \cdot \mathrm{l}^{-1}$ of Gardoprim Plus Gold $500 \mathrm{SC}$. Swelling and hydropic vacuolar degeneration of hepatocytes (arrows) $(\mathrm{HE}, \times 400)$. 